\title{
Le savoir technologique de l'Orient
}

A propos du voyage en Inde de Franz Reuleaux en 1881

\section{Britta Rupp-Eisenreich}

\section{OpenEdition}

\section{Journals}

Édition électronique

URL : https://journals.openedition.org/tc/767

DOI : $10.4000 /$ tc. 767

ISSN : 1952-420X

Éditeur

Éditions de l'EHESS

\section{Édition imprimée}

Date de publication : 1 octobre 1990

ISSN : 0248-6016

\section{Référence électronique}

Britta Rupp-Eisenreich, « Le savoir technologique de l'Orient », Techniques \&

Culture [En ligne], 14 | 1990, mis en ligne le 16 janvier 2006, consulté le 29 septembre 2022. URL :

http://journals.openedition.org/tc/767 ; DOI : https://doi.org/10.4000/tc.767

Ce document a été généré automatiquement le 29 septembre 2022.

Tous droits réservés 


\section{Le savoir technologique de l'Orient}

A propos du voyage en Inde de Franz Reuleaux en 1881

Britta Rupp-Eisenreich 